N. García \&

J. L. Arsuaga

D epartamento de Paleontología,

F acultad de Ciencias G eológicas, U .A. de Paleoantropología \& Instituto de Geología E conómica, U niversidad Complutense de $M$ adrid, Ciudad U niversitaria, 28040 M adrid, Spain

\section{T. Torres}

D epartamento de I ngeniería G eológica, E scuela T écnica Superior de Ingenieros de $M$ inas, U niversidad Politécnica de M adrid, Ríos R osas 21, 28003 M adrid, Spain

Received 16 April 1996 R evision received 1 November 1996 and accepted 2 February 1997

Keyw ords: carnivores, U rsus deningeri, M iddle Pleistocene, taphonomy, mortality profiles, Sima de los H uesos.

\section{The carnivore remains from the Sima de los Huesos Middle Pleistocene site (Sierra de Atapuerca, Spain)}

Remains of carnivores from the Sima de los H uesos site representing at least
158 adult individuals of a primitive (i.e., not very speleoid) form of U rsus
deningeri V on R eichenau 1906, have been recovered through the 1995 field
season. These new finds extend our knowledge of this group in the Sierra de
Atapuerca M iddle Pleistocene. M aterial previously classified as Cuoninae
indet. is now assigned to Canis lupus and a third metatarsal assigned in 1987 to
Panthera cf. gombaszoegensis, is in our opinion only attributable to Panthera sp. The
family M ustelidae is added to the faunal list and includes M artes sp. and a
smaller species. The presence of Panthera leo cf. fossilis, L ynx pardina spelaea and
Felis silvestris, is confirmed. The presence of a not very speloid U rsus deningeri,
together with the rest of the carnivore assemblage, points to a not very late
M iddle Pleistocene age, i.e., oxygen isotope stage 7 or older. R elative
frequencies of skeletal elements for the bear and fox samples are without major
biases. The age structure of the bear sample, based on dental wear stages, does
not follow the typical hibernation mortality profile and resembles a cata-
strophic profile. The site was not a natal or refuge den. The hypothesis that the
site was a natural trap is the most plausible. If the Sima de los H uesos
functioned as a natural trap (without an egress out), the human accumulation
cannot be attributed to carnivore activities and must be explained differently. (C) 1997 Academic Press Limited

\title{
Introduction
}

The first study of the $U$ rsus deningeri remains from the Sima de los Huesos site (in the Cueva M ayor cave, Sierra de Atapuerca), was carried out by T orres (1977), who recovered numerous bear fossils in his 1976 field season. Ceballos (1986), continued the study of the fossil bears, adding new material from the 1984 campaign. A comprehensive study of all the carnivore remains, excluding the ursids, from the A tapuerca sites G ran D olina, G aleria and Sima de los Huesos, up to and including the 1982 field campaign, was published by M orales et al. (1987), including a first faunal list and description of the several taxa: Cuoninae indet., V Vulpes vulpes Sp., F elis silvestris, Panthero leo cf. fossilis, and Panthera cf. gombaszoegensis. Finally, Cervera (1992) reported on new findings of carnivore fossils, through the 1991 campaign, from the Sierra de A tapuerca site complex (excluding the Gran D olina site), adding L ynx pardina spdaea to the SH list published by M orales et al. (1987).

The aim of this paper is update the carnivore fossil inventory through the 1995 field season, and to determine the biochronology of the site. A taphonomic study of skeletal part representation using bear and fox remains is performed, as well as a study of the bear sex distribution and mortality profile, in order to investigate the origin of the carnivore accumulation. Since the Sima de los H uesos contains the most complete sample of Middle Pleistocene humans yet discovered from one site, the origin of the carnivore accumulation reveals information also relevant as to human remains accumulated in the Sima de los $\mathrm{H}$ uesos site.

\section{Material and methods}

There are abundant $U$ rsus deningeri remains of unequivocal taxonomic identification (C eballos, 1986; Torres, 1988a,b,c,d,e,f ). Before 1991 only carnivores from disturbed sediments were 


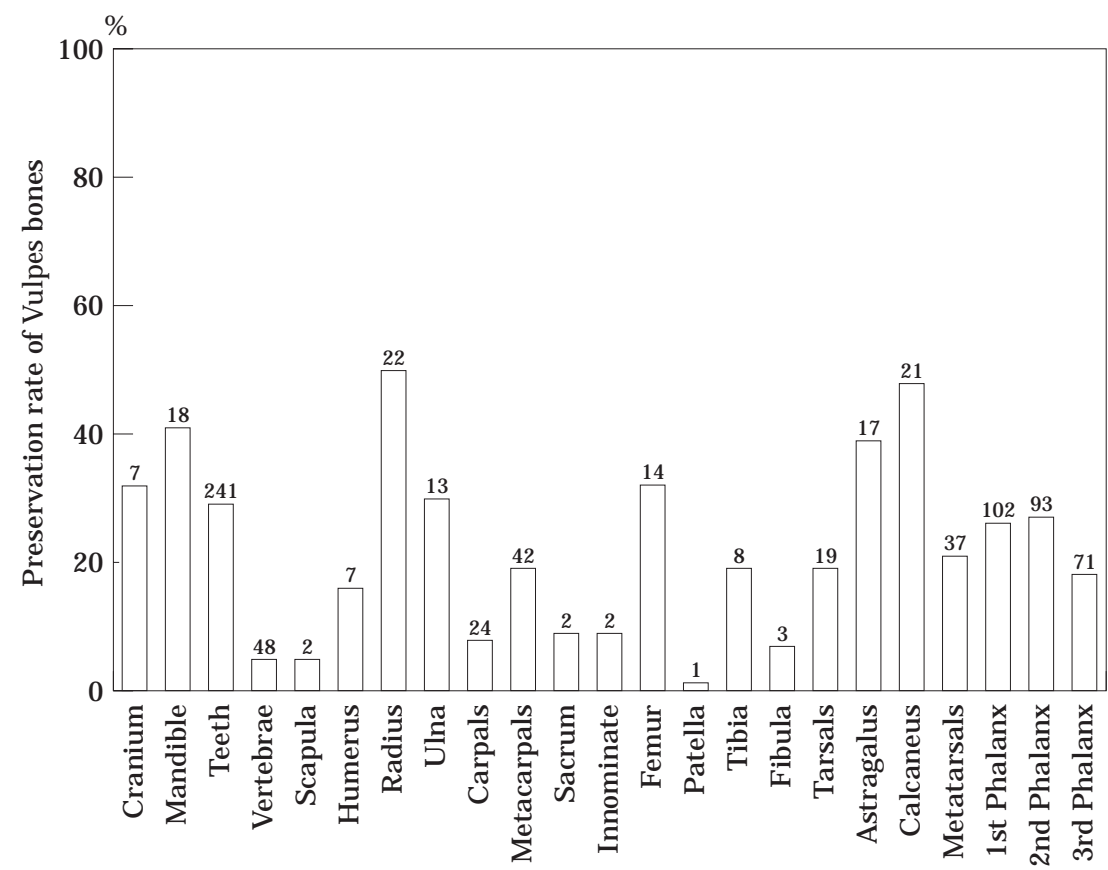

Figure 1. Preservation rate of cranial and postcranial fox bones from Sima de los H uesos. Percentages are calculated based on an M NI of 23 individuals. All skeletal parts are represented. The M NI for a particular skeletal element is calculated using that part of it (i.e., proximal end, distal end or shaft) that is more represented in the sample (on the left or right side) (following Lyman, 1994b). Numbers above each bar represent the actual number of specimens for each bone.

recovered in Sima de los Huesos $(\mathrm{SH})$. M ost of these fossils are fragmentary due to the activities of amateur collectors (Arsuaga et al., 1997). In the 1989 and 1990 campaigns, undisturbed sediments were excavated in the more distal part of the site, but no carnivore fossils were found. From the 1991 campaign through the 1995 field season, many carnivore remains have been recovered from undisturbed sediments and we have used only this sample to study skeletal part representation. Following Ricklan (1986), we have also studied the relative preservation frequencies of podial elements, and since they are generally very well preserved, all podial elements recovered since the 1984 field season (in disturbed and undisturbed sediments) are used in this article. From 1990 to 1994, three test trenches in the Sala de los Cíclopes and Sala de las $O$ seras cave chambers (also in the Cueva Mayor cave) have been excavated, resulting in the recovery of more $U$. deningeri remains.

The $\mathrm{V}$. vulpes sample is very large and a cumulative percentage graph (following T rinkaus, 1985 and Arsuaga et al., 1990) and a bone preservation rate histogram provide insight to better understand the origin of the accumulation. We have also calculated the minimum number of individuals ( $\mathrm{M} \mathrm{NI}$ ) for all taxa in $\mathrm{SH}$, in each case using the most abundant anatomical part.

Inventories for all the taxa are provided in the text, and the bear and fox inventories are also presented in Figures 1-4. All measurements are to the nearest $0.1 \mathrm{~mm}$.

Extant carnivores used for taxonomic identification were studied in the following collections: $\mathrm{N}$ ational M useum of $\mathrm{N}$ atural $\mathrm{H}$ istory, Smithsonian Institution: Panthera leo, adult individuals 


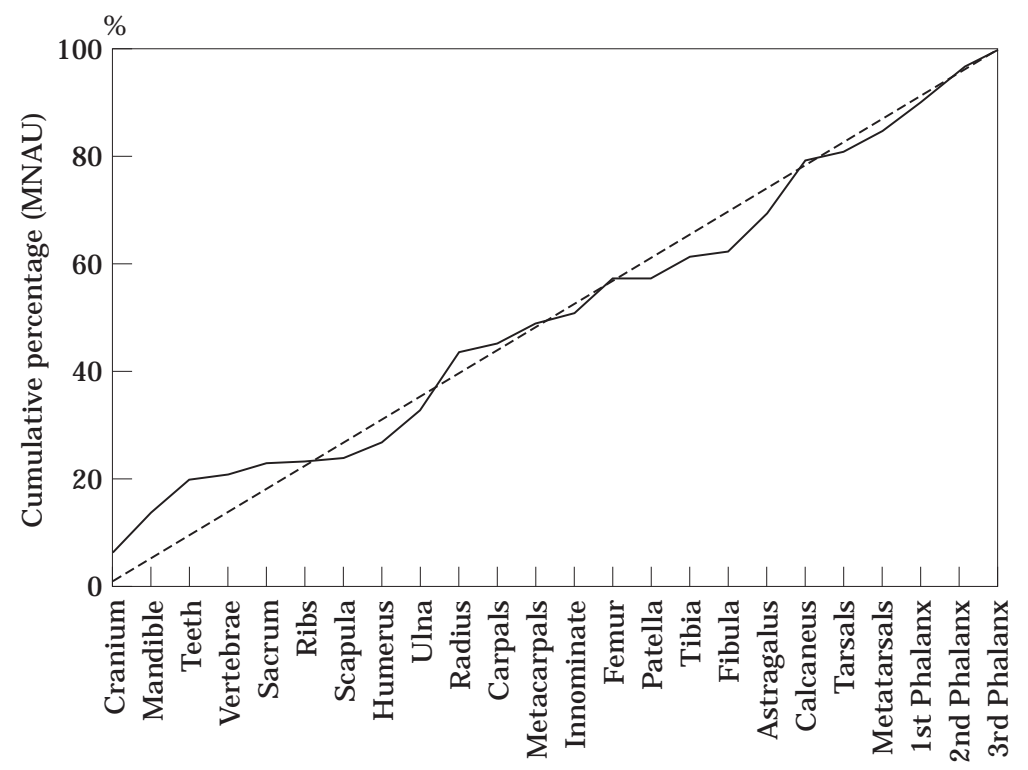

Skeletal part

Figure 2. Cumulative percentage graph of minimum number of anatomical units of fox bones. (M NAU : number of bones or bone portions preserved in sample divided by number of that bone or bone portion in a complete skeleton. The M NAU percentage for each skeletal element is with respect to the total M NAU for the sample.) (- - ) V ulpes SH ; (- - ) complete skeleton.

(postcranial, $n=8$; dentition, $n=14$ ); Panthera pardus (postcranial, $n=3$; dentition, $n=16$ ); Panthera onca (postcranial, $n=6$; dentition, $n=52$ ).

M useum of $V$ ertebrate Zoology, U niversity of California, Berkeley: a sample of five $D^{3}$ Panthera leo $\mathrm{L}$. individuals used for comparison with the specimen from $\mathrm{SH}$.

Estación Biológica de Doñana, Sevilla (C.S.I.C.): Lynx pardina (postcranial, $n=6$; dentition, $n=14)$.

Departament of Vertebrate Zoology, Facultad de Ciencias Biológicas, Universidad Complutense de M adrid. Canis lupus, V. vulpes, Felis silvestris.

Facultad de Ciencias Biológicas de la Universidad Autónoma de M adrid. M ustelidae.

\section{Felidae}

Panthera leo $\mathrm{cf}$. fossilis

Postcranial remains. O ne distal epiphysis of a tibia; one distal epiphysis of a radius; one proximal fourth of a radius; one proximal end of a second metatarsal; three tali; two calcanei; three scapholunars; two lateral cuneiforms; one third metacarpal; two fourth metacarpals; two third metatarsals; one sesamoid; five proximal phalanges; eight middle phalanges; one cervical vertebra; two caudal vertebrae.

Permanent dentition. Four $M_{1}$, four $P_{4}$, one $P^{4}$ and two $P_{3}$.

Deciduous dentition. T wo upper canines, one $D^{3}$ and one $D^{4}$. 


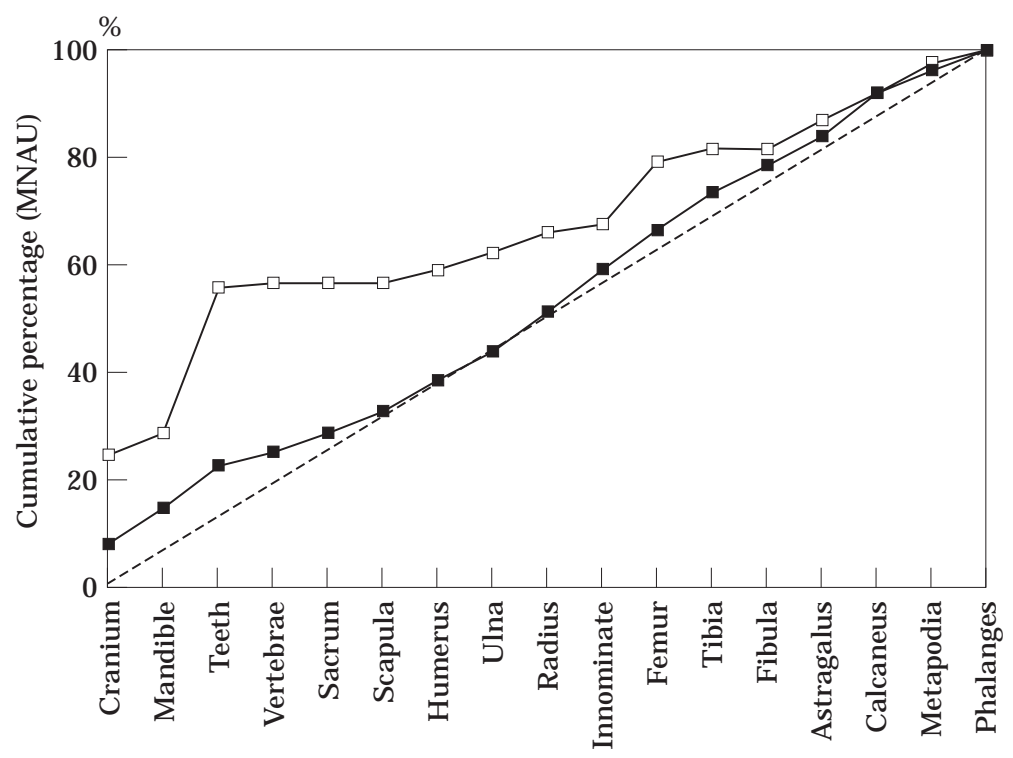

Skeletal part

Figure 3. Cumulative Percentage $\mathrm{G}$ raph of minimum number of anatomical units in $\mathrm{U}$. deningeri bones for the (घ) SH sample, and ( $\square$ ) W estbury-sub-M endip sample (Andrews \& T urner (1992). (M N AU : calculated as in Figure 2.) (- - -) Complete skeleton.

T axonomic assignation. We recovered four adult lower carnassials of Panthera leo cf. fossilis (M orales, 1987; Cervera, 1992) which are assigned to one male and one female (Figure 11) based on the pattern of sexual dimorphism in dental measurements of $P$. leo metric ( $T$ urner, 1984).

Furthermore, we have assigned a $D^{3}$ to a juvenile individual of the same species based on the measurements in T able 1 . We assume that two upper deciduous canines and an upper $\mathrm{D}^{4}$ belonging to a large felid that were recovered belong to the same immature individual (Figure 11). Thus, the M NI for this species is thus three.

Panthera sp.

Postcranial remains. Proximal two thirds of a left third metatarsal. It corresponds to a felid of considerably smaller size than P. leo cf. fossilis, and intermediate between Panthera pardus and P. leo. (Figure 10). M orales (1987) attributed this specimen to Panthera cf. gombaszoegensis based on its similarity to Panthera onca augusta dimensions (K urtén, 1973). N evertheless, Cervera (1992) only identifies P. leo cf. fossilis from the SH site because he considers the assignment of this metatarsal to a juvenile P. leo cannot be excluded. We see no juvenile features in the specimen but we prefer to refer to this specimen as Panthera sp., because although its measurements are very close to those of $\mathrm{P}$. onca augusta, they are also close to large specimens of $P$. pardus.

\section{Lynx pardina spelaea}

Postcranial remains. O ne proximal fragment of a femur; one fragment of a scapula with glenoid fossa; one scapholunar; one metacarpal; one proximal phalanx; two middle phalanges. 


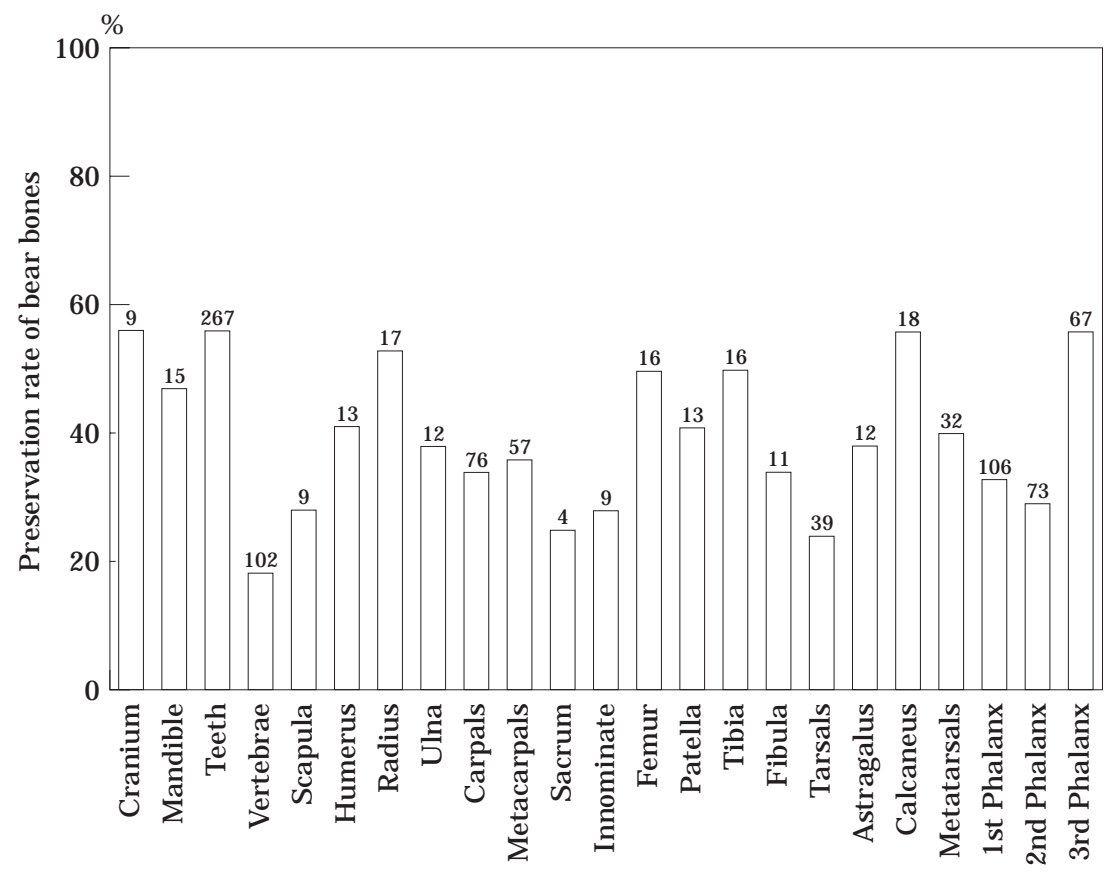

Figure 4. Preservation rate of cranial and postcranial bear bones from Sima de los $\mathrm{H}$ uesos. Percentages are calculated based on an M NI of 16 individuals. All skeletal parts are represented. The M NI for a particular skeletal element is calculated using that part of it (i.e., proximal end, distal end or shaft) that is more represented in the sample (on the left or right side). N umbers above each bar represent the actual number of specimens for each bone.

Table $1 D^{3}$ measurements in modern lions compared with the SH specimen

\begin{tabular}{|c|c|c|c|c|}
\hline & \multicolumn{2}{|c|}{$D^{3}$ length } & \multicolumn{2}{|c|}{$\mathrm{D}^{3}$ talon width } \\
\hline & M ean & S.D. & M ean & S.D. \\
\hline $\begin{array}{l}\text { Panthera leo } L \text {. } \\
\text { (extant) }(n=5) \\
\text { SH }\end{array}$ & $23 \cdot 5$ & 1.3 & 5.9 & 0.3 \\
\hline
\end{tabular}

Cranial remains. Two associated hemimandibles from the $\mathrm{SH}$ undisturbed sediments. All teeth but the incisors are associated in place. An isolated lower canine was recovered in SR M . T hus, the $\mathrm{MNI}$ in the SH sample is two.

T axonomic assignation. The Atapuerca (SH) lynx is a felid of medium size. The lower carnassials display morphological features typical of Lynx pardina differentiating it from L. Iynx, such as complete absence of a metaconid and a talonid, and a protoconid with a straight posterior edge (Figure 11). Based on dimensions, this fossil is placed in the subspecies L. pardina spelaea (Werdelin, 1981; Cervera, 1992), a temporal variant, larger than the recent L. pardina pardina, and smaller than the Villafranchian species of southern Europe, L ynx issidiorensis. 
Felis silvestris

Remains. O ne proximal phalanx, a distal epiphysis of a femur and one upper carnassial. $\mathrm{MNI}=1$. The $\mathrm{SH}$ remains belong to a small-sized felid of similar morphology and measurements to the extant wild cat. A large $\mathrm{P}^{4}$ is observed.

\section{Mustelidae}

M artes sp. (T able 2)

Postcranial remains. Four scapholunars; two os magni; one trapezium; two unciforms; one pyramidal; one calcaneus; one talus; one femur; one fragment of a scapula with glenoid fossa. The M NI is 3 based on the presence of three right scapholunars.

D entition. O ne $\mathrm{M}^{1}$, one $\mathrm{P}^{4}$, four upper canines and three lower canines.

T axonomic attribution. The attribution of these fossils to $\mathrm{M}$ artes is based on comparisons of the $\mathrm{SH}$ upper carnassial and first upper molar with Anderson's (1970) sample. Although many authors (K urtén, 1965; M iller, 1912) have tried to establish metrical and morphological characters to distinguish the species of $M$ artes, there is a large overlap between the ranges of $M$. martes, M. foina and M. vetus (the pine marten's probable ancestor) (Anderson, 1970) in the length and width of the protocone of the upper carnassial and the length and width of the inner lobe of the upper molar. In consequence, it is difficult to make a specific attribution on the basis of isolated teeth alone.

The most cited dental criterion is that the length of the upper carnassial $\left(L P^{4}\right)$ is equal to the width of upper first molar (W $\mathrm{M}^{1}$ ) in M . martes but is less than that in M . foina (Anderson, 1970). The Sima de los $H$ uesos specimen shows an $L P^{4} / W M^{1}$ relationship like that in $M$. martes (Figure 10). To express this proportion metrically, we have calculated the $L \mathrm{P}^{4} / \mathrm{WM}^{1}$ and $\mathrm{LP}^{4} / \mathrm{LM}^{1}$ ratios using A nderson's means (T able 2 ). The upper teeth from $\mathrm{SH}$ are more similar to recent $M$. martes Postglacial $M$. martes and $M$. vetus than to $M$. foina values. In addition, the values of the $L M^{1} / W^{1}$ ratio reveal that the $\mathrm{SH}$ specimen is closer to the recent and Postglacial $M$. martes populations, and the $L P^{4} / L^{1} M^{1}$ ratio shows more similarity between R ecent $M$. martes and the SH specimen. Thus, the most likely assignation for these teeth is to $M$. martes.

M ustelidae indet.

Dentition. $O$ ne $\mathrm{P}^{4}$ and two $\mathrm{M}_{1}$. $\mathrm{MNI}$ is 2 .

T axonomic assignation. These remains belong to a small mustelid, that might be attributable to M ustela.

\section{Canidae}

Canis lupus (T able 3)

Postcranial remains. O ne scapholunar; one lateral cuneiform; one pyramidal; four proximal phalanges; one middle phalanx; two fragments of two metapodials. 


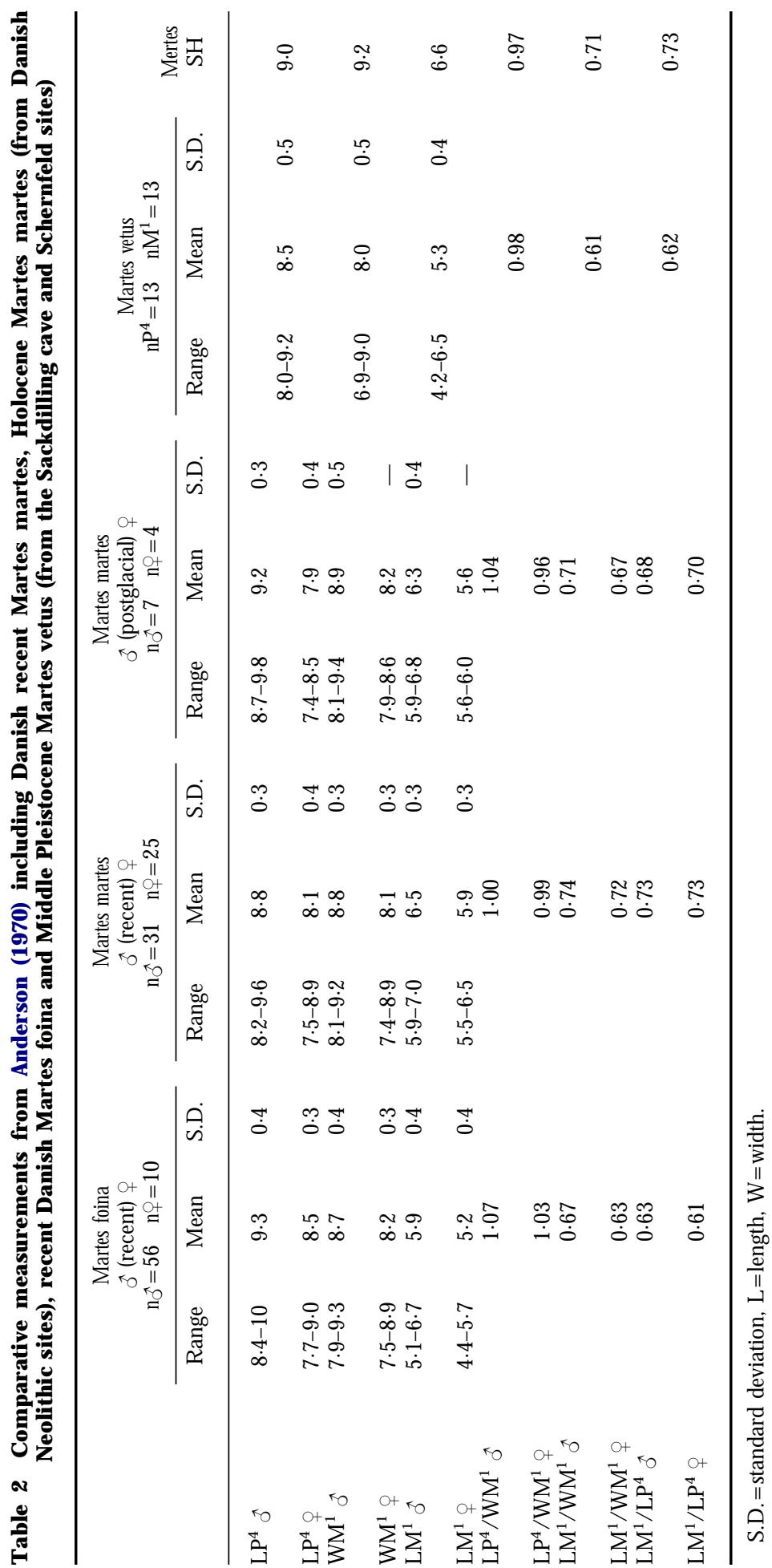


Table $3 M_{1}$ measurements of fossil wolves from the Lunel-Viel Middle Pleistocene site and SH

\begin{tabular}{|c|c|c|c|c|c|c|c|}
\hline \multirow[b]{2}{*}{ Character } & \multicolumn{3}{|c|}{$\begin{array}{c}\text { Canis lupus lunellensis } \\
\text { Lunel-V iel }\end{array}$} & \multirow[t]{2}{*}{$\begin{array}{c}\text { Canis lupus } \\
\text { SH } \\
n=1\end{array}$} & \multicolumn{3}{|c|}{ Canis lupus L. (extant) } \\
\hline & $\mathrm{n}$ & M ean & S.D. & & $n$ & M ean & S.D. \\
\hline Width $M_{1}$ & 11 & $9 \cdot 9$ & 0.42 & $10 \cdot 3$ & 10 & $11 \cdot 4$ & 0.5 \\
\hline
\end{tabular}

D ata from modern European wolves are taken from M iller (1912) cited in Altuna (1972), Altuna (1972) and from K urtén (1965) and from Lunel-V iel from Bonifay (1971).

Table $4 \mathrm{P}^{4}$ and $\mathrm{M}^{1}$ measurements of fossil foxes from the L'Escale Middle Pleistocene site and SH, and extant foxes from the Upper Peninsula of Michigan

\begin{tabular}{|c|c|c|c|c|c|c|c|c|c|}
\hline \multirow[b]{2}{*}{ Character } & \multicolumn{3}{|c|}{$\begin{array}{c}\text { Vulpes vulpes jansoni } \\
\text { L'E scale }\end{array}$} & \multicolumn{3}{|c|}{$\begin{array}{c}\text { Vulpes vulpes spp. } \\
\text { SH }\end{array}$} & \multicolumn{3}{|c|}{$\begin{array}{l}\text { Vulpes vulpes } \\
\text { recent }\end{array}$} \\
\hline & $n$ & M ean & S.D. & $n$ & M ean & S.D. & $n$ & M ean & S.D. \\
\hline $\begin{array}{l}\text { Length } P^{4} \\
\text { Width } P^{4} \\
\text { L ength } M_{1} \\
\text { W idth } M_{1}\end{array}$ & $\begin{array}{l}7 \\
6 \\
6 \\
5\end{array}$ & $\begin{array}{r}13 \cdot 9 \\
6 \cdot 7 \\
15 \cdot 6 \\
5 \cdot 8\end{array}$ & $\begin{array}{l}0.3 \\
0.6 \\
0.7 \\
0.4\end{array}$ & $\begin{array}{l}10 \\
10 \\
24 \\
23\end{array}$ & $\begin{array}{r}14 \cdot 6 \\
6 \cdot 5 \\
15 \cdot 7 \\
5 \cdot 8\end{array}$ & $\begin{array}{l}0.5 \\
0.5 \\
0.8 \\
0.5\end{array}$ & $\begin{array}{l}48 \\
50 \\
50 \\
48\end{array}$ & $\begin{array}{r}13 \cdot 9 \\
7 \cdot 3 \\
15 \cdot 4 \\
5 \cdot 8\end{array}$ & $\begin{array}{l}0.5 \\
0.4 \\
0.7 \\
0.3\end{array}$ \\
\hline
\end{tabular}

Data from L'Escale are taken from Bonifay (1971) and from extaut foxes from Gingerich \& Winkler (1979).

Dentition. O ne upper canine; a fragment of a canine crown; one $M_{1}$ (which preserves the trigonid cusps). These three pieces are at the same developmental stage, and we have assigned them to a single individual.

T axonomic attribution. Based on the size of the postcranial bones, which are larger than $\mathrm{C}$. lupus lunelensis from Lunel-V iel, M orales et al. (1987) assigned the following remains to Cuoninae indet.: B-763, B-4001, B-4002, B-4003, B-4004, B-4005 and B-4006. Later, a fragment of a left $M_{1}$ was found. $A$ reduced and poorly defined metaconid is usually considered diagnostic of the genus Cuon. The SH lower carnassial shows a well-defined metaconid substantially larger than that of Cuon alpinus europaeus from the M iddle Pleistocene Galeria site (also in Sierra de Atapuerca) (Figure 11). Comparison with $C$. Iupus lunellensis from Lunel-Viel (M iddle Pleistocene) shows that the Atapuerca SH $\mathrm{M}_{1}$ is not larger (Table 3). Moreover, cuons and wolves from the Galeria site are similar in size (Figure 10).

\section{Vulpes vulpes ( $T$ able 4)}

The most common skeletal element in the SH assemblage of foxes is the right lower carnassial which gives an $\mathrm{MNI}$ of 23 .

All remains recovered from the Sima de los $\mathrm{H}$ uesos site are similar in morphology and size to modern $\mathrm{V}$. vulpes $\mathrm{L}$. M easurements of the upper and lower carnassials are very close to those of $\mathrm{V}$. vulpes jansoni from L'Escale (T able 4). Although the SH specimens have a larger upper carnassial, absolutely and relative to its width compared with a sample of N orth American fox or the M iddle Pleistocene fox sample from L'E scale, we prefer not to assign the SH specimens to any subspecies, considering the wide size range of this species. 


\section{Ursidae}

\section{Ursus deningeri Von $R$ eich}

T axonomic assignation of the Sima de los $\mathrm{H}$ uesos ursids is based on abundant postcranial and dental remains recovered during several campaigns (see T orres, 1977; C eballos, 1985).

According to Prat (1976) U . deningeri only occurs in the M iddle Pleistocene, becoming U rsus splaeus in the late M iddle Pleistocene. Bonifay (1975), considers the ursids from La Fage to be evolved (speloid). This site is stratigraphically assigned to Riss II and R iss II-III (broadly equivalent to oxygen isotope stages 8 and 7). To Arambourg (1958) and Bonifay (1975), the probably late R issian (stage 6) sites of Fontéchevade yields a typical cave bear (U. spelaeus). In her paper of 1975, Bonifay considers U . spelaeus to succeed U. deningeri at the end of the M iddle Pleistocene although Bonifay \& Bussière (1989) classify as U . deningeri fossil remains from Aldène, from levels $\mathrm{G}$ and $\mathrm{H}$ assigned to the early $U$ pper Pleistocene. N evertheless, as $\mathrm{H}$ ennig (1982), on whose results they base their study, obtained radiometric ages which disagree with the biostratigraphical order, it is impossible to establish the chronology of these two layers. It just can be assumed that they are younger than marine isotope stage 9 . The chronology of the transition $U$. deningeri- $U$. spelaeus is thus difficult to establish, in part because of the anagenetic nature of this evolutionary process, and in part due to the lack of an accurate geochronological framework for the late M iddle Pleistocene sites. Auguste (1992) considers the ursids from Biache-Saint-V aast, to be transitional between both species. This site has been dated by thermoluminescence to $175 \pm 13 \mathrm{ka}$, and stratigraphic correlations with other sites place Biache at the end of the isotopic stage 7 (August, 1992); Y okoyama (1989) used gamma-ray spectrometry to obtain dates of $263+53-37 \mathrm{ka}$ (U -Th age) and >175 ka (U -Pa age) for the second human skull, and $182+46-31 \mathrm{ka}(\mathrm{U}-\mathrm{Th}$ ) for an animal bone. Another site that can be used to date the $U$. deningeri- $U$. spedaeus transition is Lezetxiki. Here level VII (just above the level where a human humerus was found) yielded $U$. deningeri and two bone samples from this level have been dated to $309+\infty-92 \mathrm{ka}$ and $303+\infty-114 \mathrm{ka}$ (Altuna, 1992). In level VI ursids with more speloid traits are found and bone dates are $231+49-92 \mathrm{ka}$ and $200+129-58 \mathrm{ka}$ (Altuna, 1992). In sum, the pattern that emerges is a terminal Middle Pleistocene transition from $U$. deningeri to $U$. spelaeus.

In order to discuss the evolutionary position of the Sima de los $\mathrm{H}$ uesos ursids, it is necessary to analyze in detail the three distinct anatomical regions: cranial skeleton, postcranial skeleton and dentition.

Complete cranial remains are very rare due to the fragility of the skull; however, there are abundant mandibles. These present characters typical of an archaic representative of $U$. deningeri such as small size, mandibular ramus sloped posteriorly, straight inferior margin of the horizontal ramus (convex in the last representatives of $\mathrm{U}$. deningeri and very convex in U. spelaeus, cf. Torres, 1978).

The most abundant complete remains of the postcranial skeleton are carpals, metacarpals, tarsals and metatarsals all of which show a primitive $U$. deningeri morphology. When compared with its ancestor, $U$ rsus etruscus, this species shows a robustness increase of the postcranial skeleton, especially in the limb epiphyses, whereas the diaphyses remain slender. The first metacarpal and metatarsal are shorter and the articular facets of the carpal and tarsal bones are larger.

The dental formula of the SH U. deningeri is consistent with other Middle Pleistocene populations, such as M auer, M osbach and Petralona (T orres, 1988e). The SH bears commonly show the $P_{1}$ and $P_{3}$ which never occur in $U$. spelaeus. 
Some primitive characters of $U$. etruscus (the last common ancestor of the arctoid and speloid lineages) are present in the $\mathrm{SH}$ ursid, such as the etruscoid morphology and size of $\mathrm{P}^{4}, \mathrm{P}_{4}$ and $M_{1}$, the reduced and rounded $M_{3}$, and an $M^{2}$ with a reduced, acute talon (T orres $\&$ Cervera, 1995). The metric and morphological patterns that characterize the $U$. deningeri population from SH do not correspond with transitional forms of U. spelaeus (Bonifay \& Bussière, 1989), but with a typical representative of $U$. deningeri.

Aside from the systematic excavations at Sima de los Huesos, three test excavations were also carried out at two places in Sala de los Cíclopes and one place in Sala de las 0 seras. These three chambers are inter-connected (Arsuaga et al., 1997). In the lower part of Sala de los Cíclopes, $U$. deningeri remains (including two hemimandibles) were found. These fossils belong to a juvenile and an adult. At Sala de los Cíclopes, close to the Sima de los H uesos shaft, various other $U$ rsus deningeri fossils were encountered, including the left hemimandible of a juvenile. Finally, in Sala de las 0 seras some cranial and postcranial remains assignable to $U$ rsus deningeri have been recovered.

\section{Carnivore diversity}

Some carnivore taxa are found in both $\mathrm{SH}$ and in the Galería complex (M iddle Pleistocene), also in Sierra de A tapuerca: P. leo fossilis, L. pardina spelaea, F lis silvestris, C. lupus, V. vulpes and $M$ artes sp. H owever, $U$. deningeri is not found in $G$ alería. Some scarce remains were tentatively assigned to $U$. spelaeus. Crocuta is absent in Sima de los $\mathrm{H}$ uesos and represented in Galería only by an unerupted canine. A middle size felid (Panthera sp.), not found in Galería, occurs in SH . In sum, the carnivore taxonomic diversity found in $\mathrm{SH}$ is high, corresponding to a very productive milieu. An analysis of the pollen content of three samples taken in the clay matrix of human and bear fossils in Area A (A rsuaga et al., 1997), showed that $40 \%$ of the grains $(n=129)$ corresponded to tree pollen, with Pinus, deciduous $Q$ uercus, evergreen $Q$ uercus, B etula and $F$ agus in decreasing order of abundance (G arcía-A ntón, 1987). Communities with this tree species correspond to a climate something moister and colder than the current one in the Sierra de A tapuerca. It is striking the (cuasi) absence of specialized large scavengers as hyenas. According to Turner (1995) humans could have successfully competed with hyenas for this ecological niche in Spain during the M iddle Pleistocene.

\section{Taphonomical analysis of the bear and fox samples}

The $\mathrm{V}$. vulpes bone accumulation

The sample of foxes is large enough to allow study of the relative frequencies of skeletal elements. Figure 1 reveals that all cranial and postcranial bones are represented; the less frequent elements are the smallest and most fragile bones. Before the present study not all the skeletal elements of the small carnivores (i.e., foxes and mustelids) were systematically recovered in the laboratory among the thousands of bear bone fragments. Although we have resorted part of this material and found many previously unrecognized small carnivore bones, there is still a "laboratory bias" against the smallest or less diagnostic bones. Of the teeth recovered from the site, $59.1 \%(n=120)$ are mandibular teeth and $40.8 \% \quad(n=83)$ maxillary teeth. Among the maxillary teeth, $51.8 \%$ come from the left side and $48.2 \%$ from the right side. Among the mandibular teeth, the numbers are $40.9 \%$ left and $59 \cdot 1 \%$ right. A chi-square test shows a statistically significant bias $\left(\chi^{2}=6 \cdot 74, P<0.01\right)$ in the upper teeth/lower teeth proportions in the sample, as well as in the carpal/ metacarpal index $(=24 / 42)$, but there is no 
statistically significant bias $\left(\chi^{2}=0.47, P>0.25\right)$ in the tarsal/metatarsal index $(=57 / 37)$. Concerning side biases, the ratio of left upper teeth to right upper teeth $(=43 / 40)$ does not significantly depart from a $1: 1$ ratio $\left(\chi^{2}=0 \cdot 1, P>0.5\right)$, whereas the left lower teeth/ right lower teeth ratio $(=49 / 71)$ departs significantly at the 0.05 level of probability but not at the 0.01 level $\left(\chi^{2}=4.02,0.05>p>0.025\right)$. In spite of the biases in some skeletal elements, that can be attributed to former "laboratory biases" or differential preservation of less structurally dense skeletal parts, and since there are no biases in other proportions and all the skeletal elements are present in the sample, without extreme bias, we consider that the most likely scenario is that complete foxes accumulated in the site.

Trinkaus $(1985)$ and Arsuaga et al. $(1990,1995)$ used the cumulative percentage of the minimum number of anatomical units (MNAU) to express patterns of skeletal part preservation. The M NAU are calculated as "number of bones or bone portions preserved in sample divided by number of that bone or bone portion in a complete skeleton" and "the M NAU percentage for each skeletal element is with respect to the total MNAU for the sample (i.e., sum of all M NAU )" (T rinkaus, 1985; p. 210). We have applied the same method to the SH sample of foxes. The cumulative graph for Vulpes from the Sima de los $\mathrm{H}$ uesos (Figure 2) shows preservation of all skeletal elements without major bias. This also suggests to an accumulation of whole bodies in the Sima de los $\mathrm{H}$ uesos. The surfaces of the bones show no abrasion and therefore do not seem to have been subjected to significant fluvial transport.

Gargett (1994) discusses characteristics of bone accumulations expected in fox natal dens, refuge dens or natural traps. In a natal den we would expect to find the neonate age class represented predominantly, with all skeletal elements present (see also Blanco, 1988; Lauriño $\&$ R uiz, 1986) and as well as remains of prey species (based on the analysis of excrements $90 \%$ of the diet of infant individuals in fox dens consists of vertebrates (Blanco, 1988)). A refuge den would be expected to contain a variety of scavenged or hunted animals and no fox bones; present day Spanish foxes show a slight predominance of rabbits in the diet $(26 \%)$, fewer rodents (24\%) and fewer birds (7\%) (Blanco, 1988). In a natural trap situation, we would expect to find complete fox skeletons of all age classes, perhaps with the exception of neonates, and without associated prey species. Neonate remains have not been recovered (and a bias against them is rejected since small mustelid remains have been found as well as neonate bones of other taxa). Moreover, neither rabbits nor birds occur and there are only very few micromammals (Cuenca-Bescós \& al., 1997). Although in our opinion the data are more consistent with the trap hypothesis, a pattern of incidental deaths of foxes attracted into the cave by scavenging opportunities or going in for temporary shelter cannot be completely discarded.

$T$ he $U$. deningeri bone accumulation

In our taphonomic study of the bear fossils, we have chosen not to include data on specimens from sediments disturbed by many years of activities of amateur collectors looking for bear canines and other impressive fossils (Arsuaga et al., 1997). The sample used in this analysis derives from in situ excavations in SH (areas A and B) and SR B between 1990 and 1995 (A rsuaga et al., 1997, Bischoff et al., 1997). The cumulative percentage graph (M NAU) shows preservation of all skeletal parts in both the SH (areas A and B) and the SR B excavation sites (Figure 3). Thus, we believe that the bear carcasses were complete when incorporated into this site. Although the cumulative percentage graph reflects the general pattern, and thus is not very sensitive to small biases or to biases that only occur in few elements, it does clearly show substantial differences between the very complete record of Sima de los $\mathrm{H}$ uesos, and sites such 


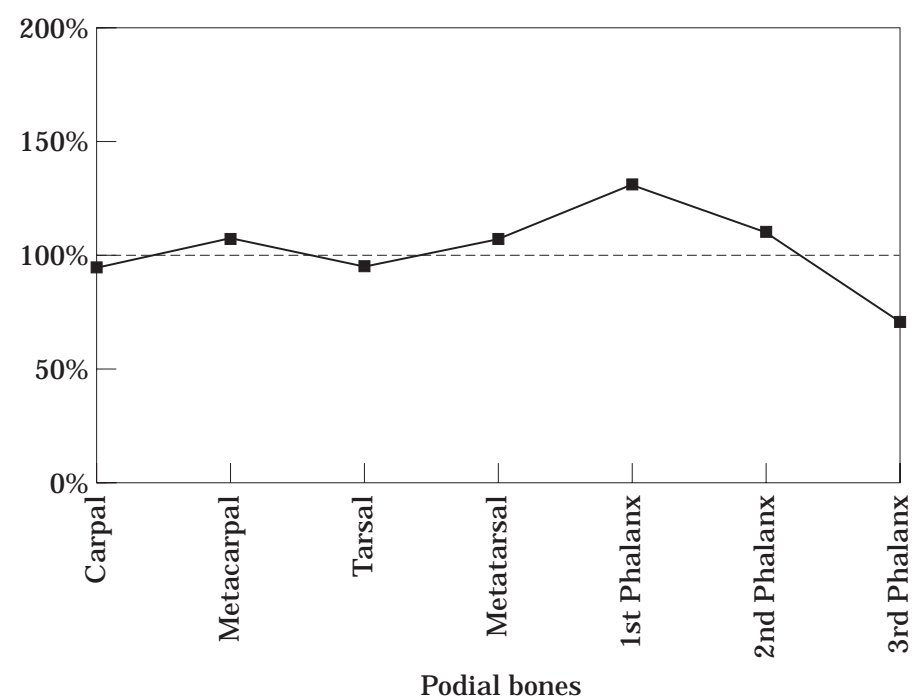

Figure 5. R elative preservation frequencies (RPF) of $U$. deningeri podials. $N$ o preservation cline from proximal to distal elements is observed.

as W estbury-sub-M endip with more bias, where yet it is stated that complete skeletons went to the deposit (Andrews \& T urner, 1992). A histogram of preservation rates of bear bones was calculated based on a $\mathrm{MNI}=16$ (Figure 4) and there are no major biases.

The M NI was calculated using the most commonly occurring skeletal element in the whole $\mathrm{SH}$ assemblage, including in this instance the fossils from disturbed sediments. For adults the left upper second molar gives a M NI of 158 adult individuals. U sing the right $D_{3}$, the M NI of immature individuals is 8 .

The ratios (left:right) for fore- and hind-feet are 6:4 $(n=367)$; metacarpals 4.6:5.4 $(n=298)$; tarsals 5.1:4.9 $(n=412)$; and metatarsals 5:5 $(n=333)$. This indicates that there is no difference in the frequency of preservation of left and right elements. $O \mathrm{f}$ a total of 1410 podials recovered (excluding phalanges) the ratio for carpals + metacarpals versus tarsals + metatarsals is 4:7:5·3.

In contrast to Ricklan's (1986) results, no preservation cline in podials from proximal to distal elements is observed. Metacarpals and metatarsals are not better preserved by comparison with carpal and tarsal bones $\left(\chi^{2}\right.$ values of 1.8 and 2.34 , respectively, both with probabilities $>0.1$ ), or phalanges, although there is a tendency for distal phalanges to be slightly less frequent in the material than proximal ones (Figure 5). Any bias against those elements have different density, mass, volume or size would exhibit such a clinical pattern if they had suffered transportation.

M ortality profiles. D ental development and attrition are used here to estimate age at death of the bears. Enamel attrition is used to estimate the age assuming a relatively constant wear rate in $U$. deningeri and U. spelaeus. Several authors have noted that these fossil bears can be grouped into clear-cut wear stages, corresponding to different ages. Since the bear fossils found in caves generally belong to individuals which died during hibernation, the wear stages thus analyzed are more discontinuous than in other carnivores that died throughout the year (K urtén, 1958; Gargett, 1994; M usil, 1965; Andrews \& Turner, 1992). 


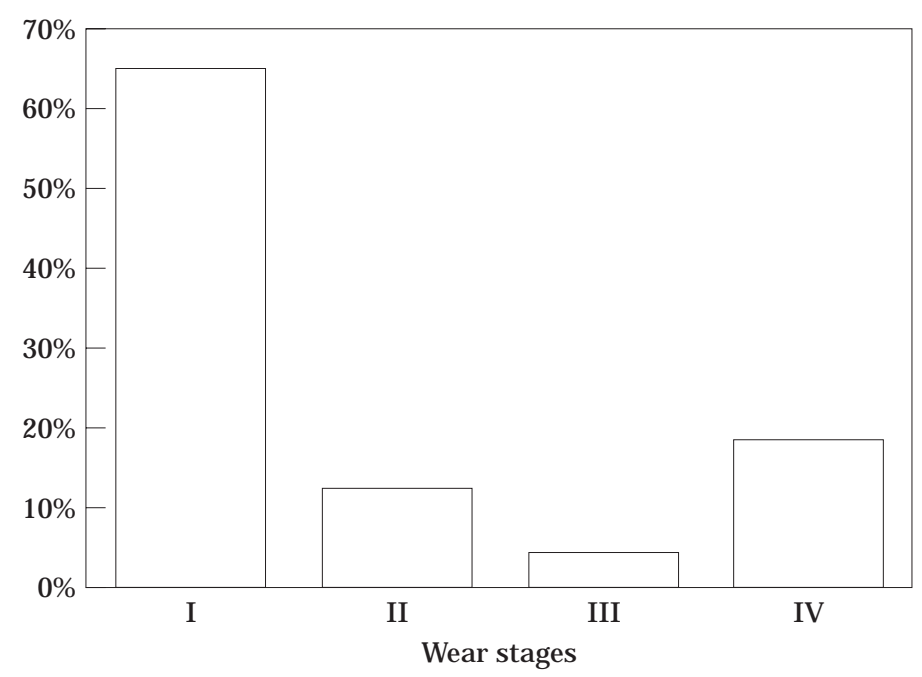

Figure 6. U rsus spelaeus mortality frequency histogram from 0 dessa. W ear determinations based on the upper second molar. Data from K urtén (1958), $n=163$. A U -shaped pattern is observed.

We have investigated the tooth that occurs most frequently in the collection, the upper second molar, that begins to develop in the first year of life and extends into the early part of the second year. While K urtén (1958) described six wear age stages, in this study we use only the four (M usil, 1965) that are clearly distinct. Furthermore we have included in Figure 8 the most abundant deciduous tooth $\left(\mathrm{d}_{3}\right)$ together with the four stages for permanent dentition, to show in a more graphic way the proportion of cubs with respect to juveniles and adults.

Stage I: T eeth with crown unworn, walls forming and roots still open at the apices (stages I and II of K urtén).

Stage II: The roots are closed, the crowns started to be polished or even have a narrow attrition facet along the internal ridge but the cusps are clearly seen (stages III and IV of K urtén).

Stage III: The facet is larger, extending to the occlusal surface of the crown with loss of a large part of enamel (stage $\mathrm{V}$ of $\mathrm{K}$ urtén).

Stage IV: The facet is even more enlarged, the enamel has already disappeared through wear, and the cementum is eroded (stage VI of K urtén).

The four wear stages are useful for interpreting the origin of the bear accumulation. Bears enter caves for hibernation and individuals that do not have sufficient fat reserves to subsist throughout the winter, are commonly very young or alternatively senile individuals ( $K$ urtén 1958). T hus, the mortality profile expected for bears dying during hibernation is an attritional pattern, with the juvenile and senile groups best represented, in a bimodal, or "U -shaped" distribution (K lein, 1984; Lyman, 1994a). That is the pattern found in U rsus spelaeus from 0 dessa (K urtén, 1958) (Figure 6) and from R eguerillo (Torres, 1974) (Figure 7).

By contrast a catastrophic mortality pattern is non-selective, and is described as a frequency distribution of age classes in which successively older age classes are represented by fewer individuals, with a unimodal or "L-shaped" frequency distribution (K lein, 1984; Lyman, 1994a). The large U. deningeri sample from Sima de los H uesos shows a mortality frequency histogram that does not correspond to the attritional distribution but does conform to the 


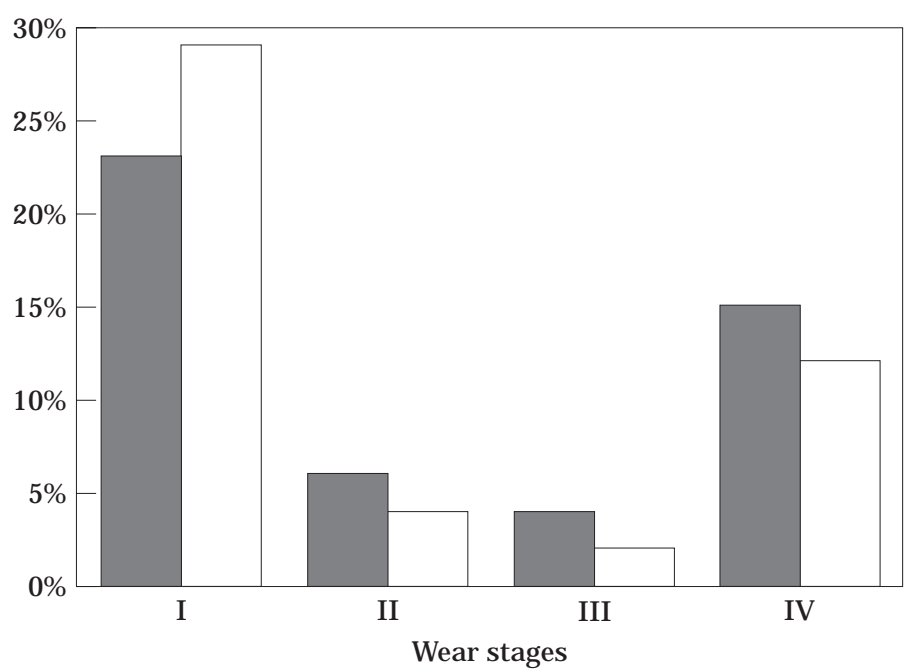

Figure 7. U rsus spelaeus mortality frequency histogram from EI R eguerillo. W ear determinations based on the upper second molar. Data from T orres (1976), n=107. A U -shaped pattern is observed. (圆) L eft; ( $\square$ ) right.

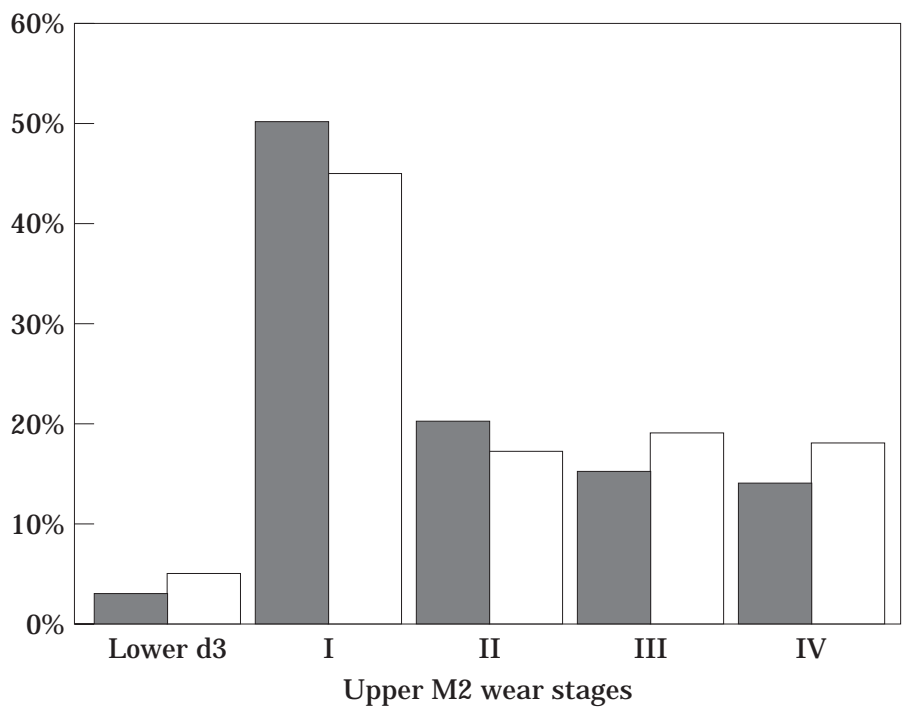

Figure 8. U rsus deningeri mortality frequency histograms from Sima de los $\mathrm{H}$ uesos. W ear determinations based on the upper second molar. Data from C eballos (1986), Torres (1988e) and our data $n=291$. The pattern is $\mathrm{L}$-shaped. At the left side of the graph, a frequency histogram of the most abundant milk tooth $\left(\mathrm{d}_{3}\right)$ of bear cubs younger than nine months shows the proportion of cubs with respect to juveniles and adults, $n=13$. (圆) Left; $\square$ ) right.

catastrophic type (Figure 8). A K olmogorov-Smirnov test performed between the $\mathrm{SH}$ and the $O$ dessa samples, although not conclusive ( $D=0.16,0.05>P>0.01)$, shows that the SH profile is unusual for a hibernation derived sample. Fossils of $U$. deningeri have also been found in Cueva Mayor, in Sala de los Cíclopes and Sala de las $O$ seras, as well as in hibernation beds. These chambers are connected to the Sima de los Huesos through a $13 \mathrm{~m}$ deep shaft 


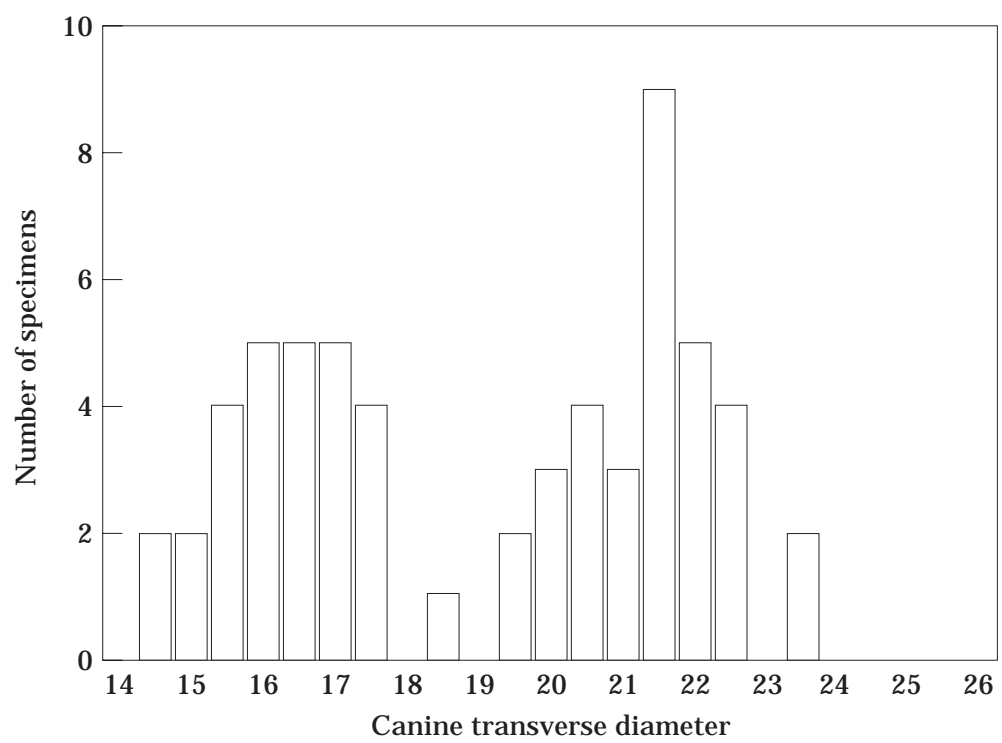

Figure 9. Frequency distribution of lower canine width in $U$ rsus spelaeus from 0 dessa $(n=63)$. N ote the bimodal distribution with lower values attributable to females and higher ones to males.

(A rsuaga et al., 1997) and it is possible that some of the bears that came into these cavities to hibernate fell down into the Sima de los $\mathrm{H}$ uesos, perhaps over a long period of time. On the other hand, the hypothesis that the SH accumulation corresponds to a place where bears hibernated and females gave birth, accessing the site through a passage (unknown) other than the shaft, is not consistent with the low neonatal (less than 1 year old) proportion (eight out of 166 , only the $4.8 \%$ of the total SH sample) relative to some U rsus spelaeus sites, such as 0 dessa, which neonatal mortality rate is about $40 \%$ of individuals (K urtén, 1958). Although very young individuals have admittedly less resistant bones, milk teeth are generally preserved in the sites, and in the Sima de los H uesos site milk teeth have been always sorted out when the sedimentary matrix is sieved looking for micromammals, so that recovery bias is excluded.

\section{Sex ratio}

Following K urtén (1969), we have used the width of the canine crown to separate males and females. A bimodal distribution is expected for a representative sample of sexually dimorphic species such as cave bears (K urtén, 1969). L ower values are attributable to females and higher ones to males (Figure 9). The SH sample of $U$. deningeri is positively skewed, with its mode at the $15 \mathrm{~mm}$ class (Figure 10) and a substantially smaller peak to the right (mode at the $19 \mathrm{~mm}$ class). I t seems that females hibernated in this part of C ueva M ayor, some of which fell into the Sima de los $\mathrm{H}$ uesos, more frequently than males. $\mathrm{O}$ ther similar cases of unbalanced sex ratios have been described for $U$. deningeri and $U$. spelaeus, and were explained by K urtén (1958) as due to a preference by females to hibernate in a cave not occupied by other bears. T he reason for this would be the possible dangerous behavior of male bears to their offspring, and in an easily defended position. 


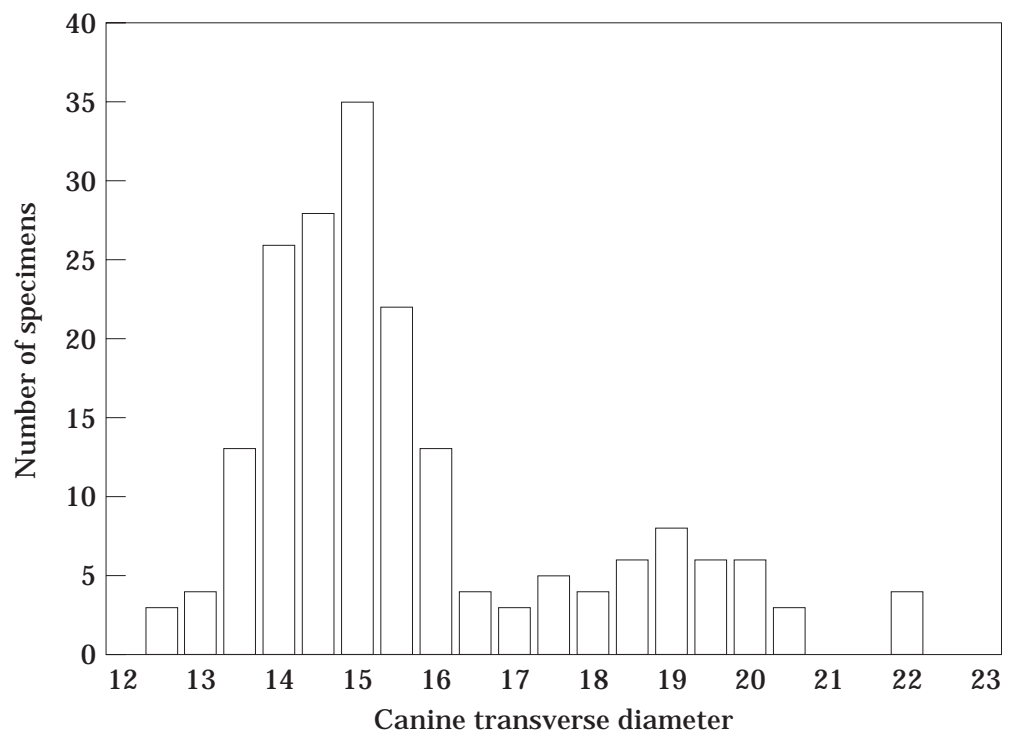

Figure 10. Distribution of canine width in U rsus deningeri from Sima de los Huesos. Data from Ceballos (1986), T orres (1988) and our data $(n=164$ teeth). N ote that the distribution is positively skewed, with a mode at the $15 \mathrm{~mm}$ class and a substantially smaller peak to the right.

\section{Summary and conclusions}

The fauna of the Sima de los Huesos site in Cueva $M$ ayor is biased in that it consists of very few micromammal (Cuenca-Bescós et al., 1997), carnivores and human remains. There is a large number of $\mathrm{U}$. deningeri $(\mathrm{M} \mathrm{NI}=158)$. A few remains of one individual of a large-sized wolf are present, whereas $\mathrm{V}$. vulpes is relatively abundant $(\mathrm{MNI}=23)$. Several differently sized felids, such as $P$. leo. cf. fossilis ( $\mathrm{MNI}=3$ ), Panthera sp. $(\mathrm{MNI}=1)$, $L$. pardina spelaea $(M N I=2)$ and $\mathrm{F}$ dis silvestris $(\mathrm{MNI}=1)$, are each represented by a few remains. There are also several mustelids, of two different sizes. No herbivores have been found. The SH carnivore sample corresponds to a typical Middle Pleistocene carnivore guild, with the exception of hyaenids, which are altogether lacking. Remains of $U$. deningeri are also abundant in the Sala de los Cíclopes and Sala de las $O$ seras chambers of Cueva M ayor, cavities to which the Sima de los $\mathrm{H}$ uesos site is connected through a $13 \mathrm{~m}$ deep shaft.

Figure 11. Carnivore remains from the $\mathrm{SH}$ site. (a) and (b) right and left lower carnassials; respectively of $P$. leo cf. fossilis, labial view; (c) and (d) right and left lower carnassials; respectively of $P$. leo cf. fossilis, lingual view; (e) and (f) proximal views of a right third metatarsal of $P$. leo cf. fossilis (e) and a left third metatarsal of Panthera sp. (f). N ote the substantial size difference between the two. (g) Left $D^{3}$ and $D^{4}$ of $P$. leo cf. fossilis, occlusal view. (h) Left $D^{3}$, labial view; same tooth as in (g). (i) Left $D^{4}$; same tooth as in (g). (j) and (k) Left and right upper decidual canines of $P$. leo cf. fossilis, lingual view. (I) L eft hemimandible of $L$. pardina spelaea, labial view. N ote the absence of a metaconid in $M_{1}$ and that the protoconid has a straight posterior edge. $(m)$ and $(n) O$ cclusal views of the left $M_{1}$ of $C$. lupus $(m)$ and $C$ uon alpinus europaeus $(n)$ from Trinchera site. $N$ ote the similarity in size. (0) R ight fragment of $\mathrm{M}_{1}$ of $\mathrm{C}$ anis lupus from $\mathrm{SH}$, lingual view. $\mathrm{N}$ ote the large metaconid observed in (m) and (o) compared with the very reduced one in (n). (p) R ight $P^{4}$ of $M$ artes sp., occlusal view. (q) L eft $M^{1}$ of $M$ artes sp., occlusal view. Scale bar represents $1 \mathrm{~cm}$. 


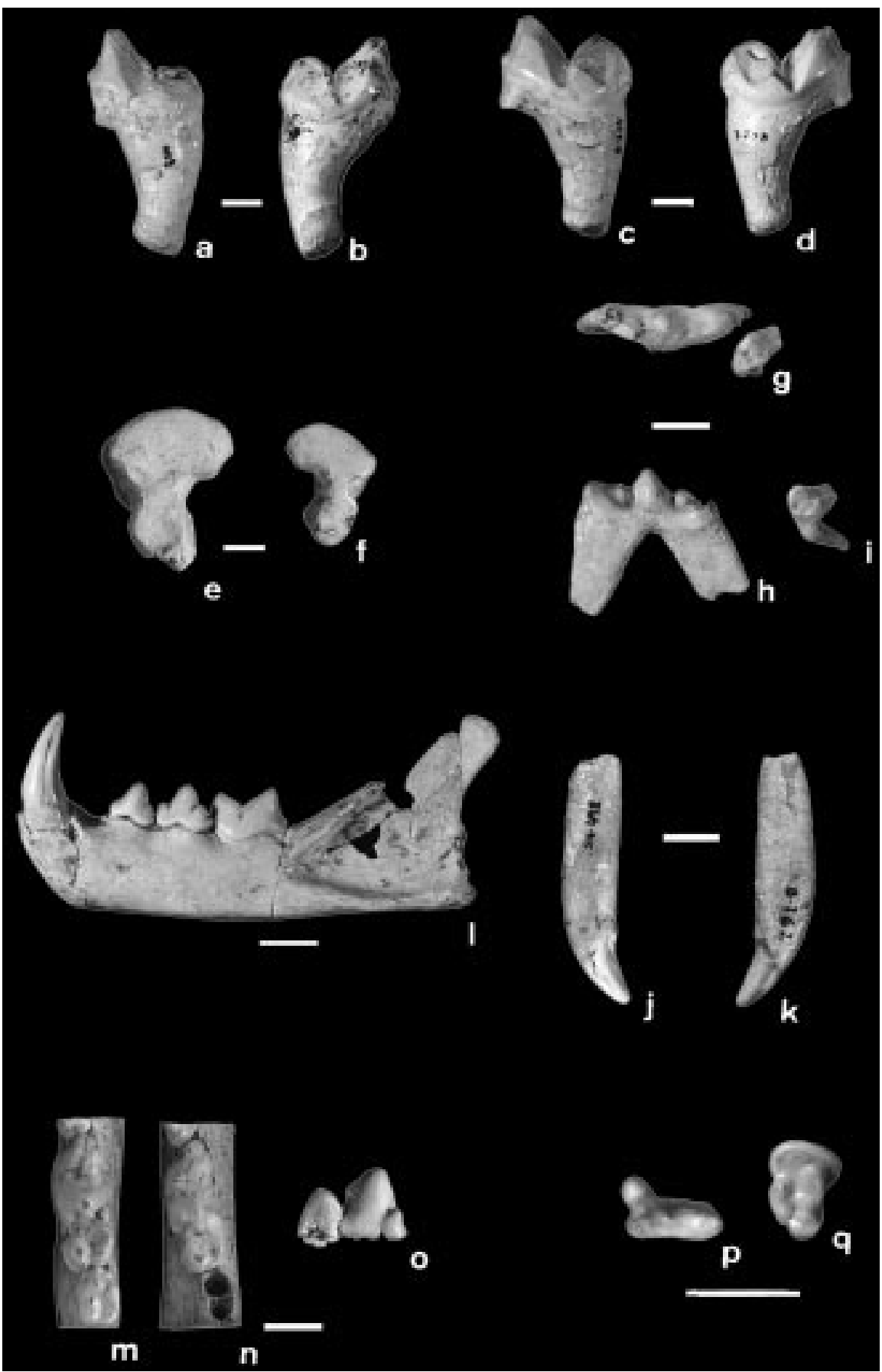


The unbiased skeletal part representation of bears and foxes indicates an accumulation of whole carcasses in Sima de los Huesos. Bears probably made use of the Cueva M ayor, and hibernated in Sala de los $C$ íclopes and Sala de las $O$ seras, but the $U$. deningeri mortality profile in Sima de los H uesos, calculated from dental wear stages, does not follow the attritional model expected under hibernation circumstances. The predominant wear stage is attributable to approximately 2 year old juveniles. Senile individuals are less well represented. M oreover, neonates are proportionally very rare. So we do not consider hibernation as the cause of death. If there was another entrance to the Sima de los H uesos (i.e., different from the shaft) in the $\mathrm{M}$ iddle Pleistocene, the other carnivores could theoretically have made occasional use of SH as a den. However the absence of prey and carnivore neonates leads us to discard both possibilities. Finally, carnivores could have been attracted by the carrion at the site or for temporary shelter and incidentally they could have died. There is no way to know if the carnivores died trapped or "naturally". N evertheless, the large number of foxes (more than 23) suggests a trap. The larger the number of foxes in the accumulation, the more unlikely is the natural death hypothesis. M oreover, the Sima de los H uesos has served as a death trap for small carnivores until the present (A rsuaga et al., 1997).

In sum, in our opinion, the carnivores did not have easy access to and exit from the site cavity. The most likely scenario compatible with the structure of the Sima de los Huesos carnivore assemblage is a natural trap (very likely the current pitfall) attracting carnivores to accidental deaths. This scenario is not compatible with carnivores being the accumulating agency for the human remains. H uman corpses had to accumulate under other circumstances (Arsuaga et al., 1997).

The V. vulpes from SH does not differ morphologically and metrically for Vulpes vul pes jansoni of L'Escale (M iddle Pleistocene) or from extant populations, although the $\mathrm{LP}^{4} / \mathrm{WP}^{4}$ ratio is slightly larger in the SH sample.

Skeletal remains previously assigned to Cuoninae indet. are now classified as $\mathrm{C}$ anis lupus based on the recovery of additional remains. The size of this canid is greater than $C$ anis etruscus from L'Escale or Canis lupus mosbachensis and is similar to Canis lupus lunellensis from the Lunel-V iel M iddle Pleistocene site.

The carnivore assemblage of the Sima de los $\mathrm{H}$ uesos, containing among other taxa, a well documented and relatively primitive form of $U$ rsus deningeri, is compatible with the upper $M$ iddle Pleistocene age suggested by the geochronological dating (Bischoff et al., 1997) and the biostratigraphic conclusions based on micromammals (Cuenca-Bescós et al., 1997). In particular, the presence of an archaic form of $U$. deningeri (i.e., not transitional to $U$. spelaeus), together with the rest of the carnivore assemblage, points to an isotope stage 7 age or (probably) older.

\section{Acknow ledgements}

This study has been supported by the Dirección G eneral de Investigación Científica y T écnica, Project N 0. PB93-0066-C 03-01. Field work is funded by Junta de Castilla y L eón. We are very grateful to Jim Patton (M useum of $V$ ertebrate Zoology U niversity of California at Berkeley), José C abot (Estacióu Biológica D oǹana) and M ichael C arleton ( $N$ ational M useum of $\mathrm{N}$ atural $\mathrm{H}$ istory, Smithsonian Institution) for providing access to the carnivore materials under his care, and for his kind help. Special thanks are given to J. M. Carretero, J. Cervera, A. G racia, C. H owell, C. Lorenzo, I. M artínez and T. White for their useful comments on the article. We also thank R. L. Lyman and three anonymous reviewers, who made very helpful suggestions to improve this paper. 


\section{References}

Altuna, J. (1972). Fauna de mamíferos de los yacimientos prehistóricos de Guipuzcoa. M unibe 24, 238-315.

Altuna, J. (1992). Le Paléolithique M oyen de la région Cantabrique. L'Anthropologie 96, 87-102.

Anderson, E. (1970). Q uaternary evolution of the genus M artes (Carnivora, M ustelidae). Acta Zool. Fennica 130, $130-132$.

Andrews, P. \& T urner, A. (1992). Life and death of the Westbury bears. Ann. Zool. Fennici 28, 139-149.

Andrews, P. \& Fernández-Jalvo, Y. (1997). Surface modification of the Sima de los H uesos fossil humans. J . hum E vol. 33, 191-217.

Arsuaga, J. L., Carretero, J. M ., G racia, A. \& M artínez, I. (1990). T aphonomical analysis of the human sample from the Sima de los huesos M iddle Pleistocene site (Atapuerca/ I beas, Spain). H um. E vol. 5, 505-513.

Arsuaga, J. L., M artínez, I., G racia, A., Carretero, J. M ., Lorenzo, C., García, N. \& O rtega, A. I. (1997). Sima de los H uesos (Sierra de Atapuerca, Spain). The site. J. hum. Evol. 33, 109-127.

Arsuaga, J. L., M artínez, I., G racia, A. \& Carretero, J. M . (1995). Los restos craneales y postcraneales de la Sima de los H uesos (Sierra de Atapuerca) y la evolución humana en el Pleistoceno M edio. In (J. M. Bermúdez de Castro, J. L. Arsuaga \& E. Carbonell, Eds.) H uman Evolution in Europe and the Atapuerca Evidence, vol. 1, pp. 283-303. $\checkmark$ alladolid: Junta de Castilla y León.

Arambourg, C. (1958). Les gros mammifères des couches tayaciennes. In (H. Alimen, G. A rambourg \& A. Schreuder, Eds) La grotte de F ontéchevade ( $3^{\mathrm{e}}$ partie), pp. 185-229. Paris: Arch, H ist. Paléont. H um. M ém. 29.

Auguste, P. (1992). É tude Archéozoologique des grands mammifères du site Plèistocene M oyen de Biache-Saint- $V$ aast (Pas-de-C alais, France): apports Biostratigraphiques et Palethnographiques. L'Anthropologie 96, 49-70.

Bischoff, J. L., Fitzpatrick, J. A., León, L., Arsuaga, J. L., Falguères, C., Bahain, J. J. \& Bullen, T. (1997). G eological relations and preliminary dating results: sedimentary fill of the Sima de los H uesos, Sierra de Atapuerca, Burgos, Spain. J. hum. Evol., 33, 129-154.

Blanco, J. C. (1988). Estudio ecológico del zorro (Vulpes vulpes), en la Sierra de Guadarrama. PhD Dissertation, Universidad de 0 viedo.

Bonifay, M . F. (1971). Carnivores Q uaternaires du Sud-Est de la France. M ém. M us. H ist. nat. Paris sér C. 21, 377.

Bonifay, M. F. (1975). Le U rsidés du gisement des Abimes de la Fage a N oailles (Corrèze) (U rsus deningeri von R eicheau). Nouv. Arch. M us. $\mathrm{H}$ ist. nat. Lyon. 13, 21-28.

Bonifay, M . F. (1976). Les carnivores: C anidés, H yaenidés, Felidés et M ustelidés. In (H . de Lumley, Ed.) La Prehistoire francaise I, 376-383. Paris: C.N.R.S.

Bonifay, M . F. \& Bussière, J. F. (1989). Les grandes faunes de la grotte d'Aldène (U rsidés). B ull. M us. Anthropol. préhist,, M onaco 32, 11-49.

Ceballos, M . (1986). Estudio biométrico y morfológico de una población de U rsus deningeri del Pleistoceno M edio de la Sierra de Atapuerca (Burgos). PhD Dissertation, U niversidad Complutense de M adrid.

Cervera, J. (1992). Nuevos hallazgos de Carnívoros en el complejo de yacimientos M esopleistocenos de la Sierra de Atapuerca, Burgos. Rev. E sp. Paleontol. Extra, 21-27.

Craighead, J. J. \& M itchell, J. A. (1982). G rizzly bear. In (M . D. Baltimore \& J. S. H opkins, Eds) W ild M ammals of N orth A merica: Biology, M anagement and Economics, pp. 515-556. The Johns H opkins U niv. Press.

Cuenca-Bescós, G., Laplana Conesa, C., Canudo, J. L. \& Arsuaga, J. L. (1997). Small mammals from Sima de los H uesos (Sierra de Atapuerca, Spain). J. hum. E vol. 33, 175-190.

García-Antón, M. (1987). Estudio preliminar de los yacimientos de la Sierra de Atapuerca (Burgos). In (E. Aguirre, E. Carbonell \& J. M. Bermúdez de Castro, Eds) EI H ombre fósil de I beas y el Pleistoceno de la Sierra de Atapuerca, I, pp. 55-59. Soria: Junta de Castilla y León, Consejería de Cultura y Bienestar Social.

García Perea, R. (1990). Variabilidad morfológica del género Lynx K err (Carnivora, Felidae). PhD Dissertation, Facultad de Ciencias Biológicas, U.C.M.

Gargett, R . H . (1994). T aphonomy and spatial analysis of a cave bear (U rsus spelaeus). Faune from Pod H radem Cave. Czech Republic: implications for the Archaeology of modern human origins. PhD Dissertation, U niversity of California at Berkeley.

Gingerich, P. D. \& Winkler, D. A. (1979). Patterns of variation and correlation in the dentition of the red fox, Vulpes vulpes. J. M ammol. 60, 4, 691-704.

$\mathrm{H}$ ennig, G . J. (1982). N otes and comments on the ${ }^{230} \mathrm{~T} \mathrm{~h} /{ }^{234} \mathrm{U}$ dating on speleothem samples from the grotte d'Aldene (C esseras, Hérault). Bull. M us. Anthropol. prèhist. M onaco 26, 21-25.

H ugueney, M. (1975). Les M ustelidés (M ammalia, Carnivora) du gisement Pléistocène M oyen de La Fage (Corrèze). Nouv. Arch. M us. H ist. nat. Lyon $\mathbf{1 3}, 29-46$.

K lein, R. G. \& Cruz-U ribe, K. (1984). The analysis of animal bones from Archaeological sites. In (K. W. Butzer \& L. G. Freeman, Eds). Prehistoric Archaeology and E cology series, $266 \mathrm{pp}$. Chicago: The U niversity of Chicago Press.

K urtén, B. (1958). Life and death of the Pleistocene cave bear. A study in Paleoecology. Acta Z ool. Fennica 95, 1-59.

K urtén, B. (1965). The Carnivora of the Palestina caves. Acta Z ool. Fennica 107, 1-74.

K urtén, B. (1969). Sexual dimorphism in fossil mammals. In (G. E. G. Westermann, Ed.) Sexual dimorphism in fossil M etazoa and taxonomic implications, pp. 226-233. Stuttgart.

K urtén, B. (1973). Pleistocene Jaguars in N orth America. Commentationes B iologicae 62, 1-23. 
K urtén, B. \& Poulianos, A. N. (1980). Fossil Carnivora of Petralona cave, status of 1980. Anthropos 8, 9-56.

L auriño, M . \& R uiz, S. (1986). Señales de permanencia animal en las cavernas. In (Servicio de publicaciones de A lava, Ed.) E studios Instituto alavés de la naturaleza 1, pp. 43-140. V itoria-G asteiz: Diputación Foral de Álava.

Lyman, R. L. (1994a). Vertebrate T aphonomy. Cambridge: Cambridge U niversity Press.

Lyman, R. L. (1994b). Q uantitative units and terminology in zooarchaeology. Am. Antiq. 59, 36-71.

M orales, J., Soria, D. \& Soto, E. (1987). Los carnívoros del Pleistoceno medio de Atapuerca. In (E. Aguirre, E. Carbonell \& J. M. Bermúdez de Castro, Eds) El Hombre fósil de Ibeas y el Plesstoceno de la Sierra de Atapuerca I, pp. 135-152. Soria: Junta de Castilla y León, Consejería de Cultura y Bienestar Social.

M iller, G. S. (1912). Catalogue of the mammals of Western Europe. 673 pp. B rit. M us. (Nat. H ist.), London.

M usil, R. (1965). Die bärenhöle PO D HRADEM die entwicklung der hölenbären in letzen glacial. Anthropozoicum, 1965.

Pérez-G onzález, A., Aleixandre, T., Pinilla, A., Gallardo, J., Benayas, J., M artínez, M. J. \& O rtega, A. I. (1995). A proximación a la estratigrafía de G alería en la T rinchera de la Sierra de Atapuerca (Burgos). In (V. M. Bermúdez de Castro, J. L. Arsuaga \& E. Carbonell, Eds) H uman E volution in E urope and the A tapuerca Evidence, vol. 1, pp. 57-73. Valladolid: Junta de Castilla y León.

Parmalee, P. W. \& Jacobson, K. W. (1959). Vertebrate remains from a M issouri cave. J. M ammol. 40, 3, 401-405.

Prat, F. (1976). Les carnivores: U rsidés. In (H. D e Lumley, Ed.) La Prehistoire francaise I, pp. 376-383. Paris: C.N.R.S.

R icklan, D. E. (1986). The differential Frequency of preservation of Early $\mathrm{H}$ ominid W rist and $\mathrm{H}$ and Bones. $\mathrm{H}$ um. Evol. 1, 373-382.

Tobias, P. V. (1987). On the relative frequencies of hominid maxillary and mandibular teeth and jaws as taphonomic indicators. H um. E vol. 2, 297-309.

Torres, T . (1974). El oso de las cavernas de la cueva del Reguerillo, Torrelaguna (M adrid). R esúmenes III Congreso $\mathrm{N}$ al. Espeleología (M adrid). Ed. Federación española de M ontaña. Comité castellano-centro de Espeleología.

Torres, T. (1977). Los osos fósiles de la sierra de Atapuerca. B ol. Geol. y. M in. 89, 2, 123-132.

Torres, T . (1978). Estudio comparativo de las mandibulas de U rsus spelaeus R os.-H ein, U rsus deningeri V on. R eich. y U rsus arctos L. Bol. G eol. y M in. 89, 3, 203-222.

Torres, T. (1987). U rsidos del Pleistoceno M edio del complejo de Atapuerca. In (E. Aguirre, E. Carbonell \& J. M . Bermúdez de Castro, Eds) El H ombre fósil de I beas y el Pleistoceno de la Sierra de A tapuerca I, pp. 135-152. Soria: Junta de Castilla y León, Consejería de Cultura y Bienestar Social.

Torres, T. (1988a). O sos (M ammalia, Carnivora, U rsidae) del Pleistoceno Ibérico (U rsus spelaeus R os.-H ein, U rsus deningeri Von. Reich. y U rsus arctos L.). I. Filogenia, distribución estratigráfica y geográfica. Estudio anatómico y métrico del cráneo. B ol. Geol. y M in. 99, 1, 3-46.

Torres, T. (1988b). O sos (M ammalia, Carnivora, U rsidae) del Pleistoceno Ibérico (U rsus spelaeus R os.-H ein, U rsus deningeri $V$ on. R eich. y U rsus arctos L.). II Estudio anatómico y métrico de la mandíbula, hioides y atlas. B ol. G eol. M in. 99, 2, 58-87.

Torres, T. (1988c). O sos (M ammalia, Carnivora, U rsidae) del Pleistoceno Ibérico (U rsus spelaeus R os.-H ein, U rsus deningeri $V$ on. R eich. y U rsus arctos L.). III Estudio anatómico y métrico del miembro torácico, metacarpo y carpo. B ol. Geol. M in. 99, 3, 44-100.

Torres, T. (1988d). O sos (M ammalia, Carnivora, U rsidae) del Pleistoceno Ibérico (U rsus spelaeus R os.-H ein, U rsus deningeri V on. Reich. y U rsus arctos L.). IV Estudio anatómico y métrico del miembro pelviano, tarso, metatarso y falanges. B ol. Geol. M in. 99, 4, 46-107.

Torres, T. (1988e). O sos (M ammalia, Carnivora, U rsidae) del Pleistoceno Ibérico (U rsus spelaeus R os.-H ein, U rsus deningeri $V$ on. R eich. y U rsus arctos L.). V Estudio anatómico y métrico de la dentición decidual y de la dentición definitiva superior. Bol. Geol. M in. 99, 5, 660-714.

Torres, T. (1988f ). O sos (M ammalia, Carnivora, U rsidae) del Pleistoceno Ibérico (U rsus spelaeus R os.-H ein, U rsus deningeri $V$ on. R eich. y U rsus arctos L.). V Estudio anatómico y métrico de la dentición inferior. B ol. Geol. M in. 99, 6, 52-106.

Torres, T \& C ervera, J. (1995). M ultivariate Analysis of the dental morphology of Plio-Pleistocene U rsids, with some observations concerning the phylogenetic position of $U$ rsus deningeri $V$ on R eichenau from Cueva M ayor (Sima de los H uesos, A tapuerca). In (J. M. Bermúdez de Castro, J. L. Arsuaga \& E. C arbonell, Eds) H uman E volution in E urope and the A tapuerca Evidence 1, pp. 123-135. V alladolid: Junta de Castilla y León

Trinkaus, E. (1985). Cannibalism and burial at K rapina. J. hum. Evol. 14, 203-216.

T urner, A. (1984). Dental sex dimorphism in European lions (Panthera leo L.) of the Upper Pleistocene: Palaeoecological implications. Ann. Zool. Fennici 21, 1-8.

Turner, A. (1995). Variaciones regionales en la fauna de grandes mamíferos del Pleistoceno Inferior y M edio de Europa. U na perspectiva I bérica. In (J. M. Bermúdez de Castro, J. L. Arsuaga \& E. C arbonell, Eds) H uman E volution in Europe and the Atapuerca E vidence 1, pp. 57-73. Valladolid: Junta de Castilla y León.

Werdelin, L. (1981). The evolution of lynxes. Ann. Z ool. Fennici 18, 37-71.

Yokoyama, Y. (1989). Direct gamma-ray spectrometric dating of anteneandertalian and neandertalian human remains. In (G. Giacobini, Ed.) H ominidae. Proceedings of the 2nd international C ongress of $\mathrm{H}$ uman Paleontology, pp. 387-390. M ilano: Jaca Book. 